\title{
TINGKAT MINAT BACA SISWA SD NEGERI 05 KUBANG PUTIAH MELALUI PENERAPAN DROP EVERYTHING AND READ (DEAR)
}

\author{
Desi Widia Astuti*), dan Malta Nelisa**) \\ Program Studi Perpustakaan dan Ilmu Informasi, Universitas Negeri Padang, Indonesia \\ E-mail: desiwidiaa@gmail.com
}

Naskah diterima: 30 Maret; direvisi: 11 Juni; disetujui: 29 Juni 2021

\begin{abstract}
.Abstrak
Penelitian ini bertujuan untuk mendeskripsikan tingkat minat baca Siswa SD Negeri 05 Kubang Putiah melalui penerapan Drop Everything And Read (DEAR) berdasarkan indikator: (1) perasaan senang; (2) pemusatan perhatian; (3) penggunaan waktu; (4) motivasi untuk membaca; (5) emosi dalam membaca; (6) usaha untuk membaca. Penelitian ini merupakan penelitian kuantitatif dengan metode deskriptif. Populasi dari penelitian ini adalah seluruh siswa SD Negeri 05 Kubang Putiah yang berjumlah 156 orang. Pengambilan sampel pada penelitian ini menggunakan teknik simple random sampling yaitu dengan pengambilan sampel secara acak tanpa memperhatikan starta yang ada dalam populasi dan dengan jumlah sampel berjumlah 61 orang. Data penelitian ini diperoleh melalui penyebaran kuesioner. Hasil penelitian ini sebagai berikut: (1) perasaan senang bernilai positif dengan skor 2,85 yang menunjukan siswa merasa senang membaca buku; (2) indikator pemusatan perhatian bernilai positif dengan skor 2,78 yang menunjukan perhatian siswa untuk kegiatan membaca baik; (3) indikator penggunaan waktu bernilai positif dengan skor 2,54 yang menunjukan siswa sudah mempu menggunakan waktu secara efesien untuk membaca; (4) indikator motivasi untuk membaca bernilai positif dengan skor 2,79 yang menunjukan siswa memiliki motivasi yang baik untuk membaca; (5) indikator emosi dalam membaca bernilai positif dengan skor 2,58 yang menunjukan siswa mampu menunjukan emosi yang baik saat membaca; (6) indikator usaha untuk membaca bernilai positif dengan skor 2,74 yang menunjukan siswa telah melakukan usaha untuk bisa membaca. Secara keseluruhan tingkat minat baca Siswa SD Negeri 05 Kubang Putiah melalui penerapan Drop Everything And Read (DEAR) bernilai positif dengan skor 2,71 yang menunjukan tingkat minat baca siswa SD Negeri 05 Kubang Putiah dinilai baik. Skor tertinggi pada indikator perasaan senang dan skor terendah pada indikator penggunaan waktu.
\end{abstract}

Kata kunci: Drop Everything And Read (DEAR), membaca, minat baca siswa.

\begin{abstract}
This study aims to describe the level of reading interest of students at SD Negeri 05 Kubang Putiah through the application of Drop Everything And Read (DEAR) based on the following indicators: (1) feeling of pleasure; (2) concentration; (3) use of time; (4) motivation to read; (5) emotions in reading; (6) attempts to read. This research is a quantitative research with descriptive method. The population of this study were all students of SD Negeri 05 Kubang Putiah, totaling 156 people. Sampling in this study using simple random sampling technique, namely by taking random samples without paying attention to the existing statistics in the population and with a total
\end{abstract}


sample of 61 people. The research data were obtained by distributing questionnaires. The results of this study are as follows: (1) the feeling of pleasure is positive with a score of 2.85 which indicates that students feel happy reading books; (2) the indicator of concentration of attention is positive with a score of 2.78 which shows the attention of students for reading activities well; (3) the time use indicator is positive with a score of 2.54, which shows that students are able to use time efficiently for reading; (4) the motivation indicator for reading is positive with a score of 2.79 which indicates that students have good motivation to read; (5) the emotional indicator in reading is positive with a score of 2.58 which indicates that students are able to show good emotions when reading; (6) the indicator of the effort to read is positive with a score of 2.74 which indicates that the student has made an effort to be able to read. Overall, the level of reading interest of students of SD Negeri 05 Kubang Putiah through the application of Drop Everything And Read (DEAR) is positive with a score of 2.71 which shows that the level of reading interest of students of SD Negeri 05 Kubang Putiah is considered good. The highest score on the feeling of pleasure indicator and the lowest score on the indicator of time use

Keywords: Drop Everything And Read (DEAR), reading, reading interest

\section{PENDAHULUAN}

Salah satu pondasi dasar menciptakan SDM Indonesia yang unggul yaitu dengan menumbuhkan minat baca di tengah masyarakat. Budaya baca memiliki peran yang sangat penting dalam kehidupan karena ilmu pengetahuan dihasilkan dari membaca. Namun faktanya, minat baca masyarakat Indonesia khususnya anakanak masih tergolong rendah. Peryataan tersebut dibuktikan dari surrvei yang dilakukan oleh UNESCO bahwa Indonesia merupakan urutan kedua dari bawah soal literasi dunia, artinya minat baca masih sangat rendah. Menurut data UNESCO minat baca Indonesia hanya berkisar 0,001\% artinya dari 1000 orang hanya 1 yang rajin membaca (Kominfo, 2017). Melihat kenyataan yang terjadi tersebut, Indonesia harus mampu meningkatkan minat baca masyarakatnya agar mampu berkompetisi dengan negara maju untuk menghasilkan SDM yang memiliki kecerdasan tinggi.

Untuk mengatasi rendahnya minat baca di Indonesia maka perlu ditanamkan kebiasaan membaca sedari dini. Masa anakanak merupakan waktu yang paling tepat untuk menumbuhkan kebiasaan baik sehingga dapat terbawa sampai dewasa. Indonesia telah melakukan berbagai cara agar mampu meningkatkan minat baca anak. Telah banyak program yang dibuat oleh pemerintah agar minat baca anak di Indonesia meningkat antara lain yaitu gerakan literasi sekolah, program morning reading, dan program lainnya. Programprogram tersebut dapat dilakukan dengan berbagai metode, salah satunya yaitu Metode Drop Everything And Read atau dapat disingkat dengan DEAR.

Drop Everything And Read (DEAR) dapat diartikan dengan "Tinggalkan semua aktifitas dan bacalah" secara tidak langsung dapat menumbuhkan minat baca siswa. Menurut Nikki Heath (dalam Usaid Prioritas ,2015) Drop Everything And Read (DEAR) dilakukan secara rutin selama 10-20 menit secara bersama oleh seluruh civitas akademik sekolah atau serendahnya dilakukan oleh satu kelas agar siswa menjadi semangat dan termotivasi untuk membaca. Drop Everything And Read (DEAR) berfokus kepada membaca adalah hal yang menyenangkan sehingga para siswa dapat berlomba-lomba dalam meningkatkan minat baca mereka. Selain civitas akademik, perpustakaan sekolah juga menjadi faktor terpenting dalam penyediaan bahan bacaan selama dilaksanakannya Drop Everything And Read (DEAR). Koleksi bahan bacaan pada perpustakaan harus senantiasa 
diperbaharui yang terdiri dari buku-buku yang digemari oleh para siswa.

SD Negeri 05 Kubang Putiah merupakan salah satu sekolah dasar yang turut aktif dalam meningkatkan minat baca siswa menggunakan Drop Everything And Read (DEAR) yang sudah diterapkan sejak 2018. Sebelum pemerintah dan sekolah menerapkan program-program yang bertujuan untuk meningkatkan minat baca siswa Indonesia pada saat sekarang ini tingkat minat baca siswa tergolong rendah yaitu, dari siswa yang berjumlah 156 orang hanya 12 orang siswa yang berkunjung ke perpustakaan sekolah untuk membaca atau hanya sekedar berkunjung. Hal tersebut menjadi sesuatu yang perlu diperhatikan oleh sekolah agar kebiasaan membaca pada siswa dapat tumbuh sedari dini.

Berdasarkan wawancara dengan salah satu guru di SD Negeri 05 Kubang Putiah minat baca siswa yang tergolong rendah yaitu 7,6\% terjadi karena kurangnya motivasi membaca dari diri siswa maupun dari guru kepada siswa. Drop Everything And Read (DEAR) masuk ke dalam jadwal Gerakan Literasi Sekolah bersama dengan literasi matematika, pramuka, dan kegiatan lainnya. Sejak Drop Everything And Read (DEAR) diterapkan dari tahun 2018 terdapat peningkatan minat baca siswa menjadi $16,02 \%$ atau bisa dikatakan terjadi peningkatan dua kali lipat dari sebelumnya.

Peningkatan minat baca tersebut tidak lepas dari motivasi yang diberikan guru kepada siswa untuk selalu membaca agar wawasan yang dimiliki luas. Motivasi yang diberikan oleh guru yaitu memberi nilai tambahan kepada siswa yang berani menyampaikan apa yang dibaca selama Drop Everything And Read (DEAR) dilaksanakan ke depan kelas. Dengan adanya motivasi tersebut siswa menjadi senang dan terpacu untuk membaca dan menyampaikan apa yang telah dibaca didepan kelas. Motivasi selanjutnya yang diberikan oleh guru yaitu dengan memajang hasil tulisan siswa berupa puisi di dalam kelas. Puisi tersebut ditulis oleh siswa sebagai hasil dari apa yang telah dibaca oleh siswa selama Drop Everything And Read (DEAR) dilaksanakan. Puisi yang terbaik kemudian dipajang oleh guru di dalam kelas sehingga siswa yang karyanya tidak dipajang menjadi termotivasi dan lebih giat lagi dalam membaca untuk menggali ilmu yang kemudian dituangkan kedalam bentuk tulisan. Tingkat tertinggi dari motivasi yang diberikan oleh guru yaitu mengikutsertakan lomba kepada siswa yang memiliki tingkat minat baca yang tinggi serta aktif dalam menuangkan apa yang telah dibacakannya dengan siswa lain ataupun tulisan.

Namun selama pandemi Covid-19 kegiatan Drop Everything And Read (DEAR) tidak terlaksana secara maksimal dikarenakan jadwal waktu pelajaran selama sehari yang tidak full dan kelas dilaksanakan dengan sistem shift. Kemudian selama libur pandemi siswa diharuskan untuk selalu melihat ponsel sehingga minat siswa untuk membaca berkurang.

Berdasarkan wawancara tersebut ditemukan, pertama rendahnya minat baca siswa. Sebelum diterapkannya Drop Everything And Read (DEAR) minat baca siswa tergolong rendah yaitu sekitar 7,6\% dari seluruh jumlah siswa. Berdasarkan observasi awal dari seluruh siswa yang berjumlah 156 orang, hanya sekitar 12 orang siswa yang berkunjung ke perpustakaan sekolah untuk membaca. Minat baca siswa yang rendah disebabkan karena kurangnya motivasi siswa dan guru tentang arti penting membaca. Selain kurang motivasi minat baca rendah juga disebabkan oleh tidak adanya waktu khusus yang diberikan oleh sekolah sebelum Drop Everything And Read (DEAR) diterapkan. Sehingga murid kesekolah hanya untuk mendapatkan pengetahuan akademik semata.

Kedua, penerapan Drop Everything And Read (DEAR) yang belum dilaksanakan secara maksimal. Berdasarkan wawancara dengan salah satu siswa mengatakan bahwa selama penerapan Drop Everything And Read (DEAR) waktu kapan dilaksanakannya Drop Everything And Read (DEAR) tidak ditentukan secara jelas oleh guru. 
Selanjutnya bahan bacaan yang tersedia di pojok baca kelas tidak diganti secara rutin oleh guru sehingga terkadang siswa merasa bosan membaca buku yang telah di ulang. Selama pandemi Covid-19 kegiatan DEAR tidak terlaksana secara maksimal dikarenakan jadwal waktu pelajaran selama sehari yang tidak penuh dan kelas dilaksanakan dengan sistem shift. Kemudian selama libur pandemi siswa diharuskan untuk selalu melihat ponsel sehingga minat siswa untuk membaca berkurang.

Berdasarkan permasalahan tersebut maka penulis merasa perlu melakukan penelitian terkait tingkat minat baca siswa SDN 05 Kubang Putiah melalui penerapan Drop Everything And Read (DEAR).

\section{METODE PENELITIAN}

Penelitian ini menggunakan pendekatan kuantitatif dengan metode deskriptif. Menurut Sugiyono (2017) penelitian kuantitatif merupakan metode penelitian yang digunakan untuk meneliti pada populasi dan sampel tertentu, pengumpulan data menggunakan instrumen penelitian, analisis data bersifat kuantitatif/statistik, dengan tujuan untuk menguji hipotesis yang telah ditetapkan.

Populasi pada penelitian ini adalah seluruh siswa di SD Negeri 05 Kubang Putiah yang berjumlah 156 orang siswa. Teknik pengambilan sampel pada penelitian ini menggunakan teknik simple random sampling. Simple random sampling merupakan teknik pengambilan sampel yang dilakukan secara acak tanpa memperhatikan starta yang ada dalam populasi tersebut Sugiyono (2017). Rumus yang digunakan untuk menentukan besar sampel adalah rumus Slovin yang berjumlah 61 orang.

Variabel dalam penelitian ini adalah minat baca siswa SDN 05 Kubang Putiah melalui penerapan Drop Everything And Read (DEAR). Setiap indikator minat baca akan dikembangkan dalam bentuk pertanyaan pada lembar kuisioner. Indikator minat tersebut meliputi: (1) perasaan senang, (2) pemusatan perhatian,
(3) penggunaan waktu, (4) motivasi untuk membaca, (5) emosi dalam membaca, (6) usaha untuk membaca.

Data dalam penelitian ini diperoleh langsung dari siswa SD Negeri 05 Kubang Putiah yang menjadi responden melalui instrumen kuesioner yang disebarkan dan kemudian diolah. Kuesioner diberikan kepada sampel sebanyak 61 orang siswa.

Instrumen penelitian adalah alat yang digunakan dalam mengukur objek yang diamati dalam penelitian. Menurut Sugiyono (2017) instrumen penelitian adalah suatu alat yang digunakan untuk mengukur fenomena alam maupun sosial yang diamati. Fenomena tersebut dinamakan variabel penelitian. Dengan demikian jumlah instrumen yang akan digunakan untuk penelitian akan tergantung pada jumlah variabel yang diteliti.

Instrumen yang digunakan dalam penelitian ini adalah kuesioner berdasarkan Iindikator menurut Shaleh, dkk (2004) untuk pengumpulan data yang bersifat tertutup yaitu kuesioner dibagikan langsung kepada siswa SD Negeri 05 Kubang Putiah sebanyak 61 orang siswa sebagai sampel penelitian dan 30 siswa diluar populasi sebagai uji coba kuesioner.

\section{Kisi-Kisi kuesioner}

\begin{tabular}{|c|l|}
\hline Variabel & \multicolumn{1}{|c|}{ Indikator } \\
\hline \multirow{4}{*}{ Minat baca } & Perasaan senang \\
\cline { 2 - 2 } & Pemusatan perhatian \\
\cline { 2 - 2 } & Penggunaan waktu \\
\cline { 2 - 2 } & Motivasi untuk membaca \\
\cline { 2 - 2 } & Emosi dalam membaca \\
\cline { 2 - 2 } & Usaha untuk membaca \\
\hline
\end{tabular}

Teknik pengumpulan data merupakan suatu cara yang dilakukan oleh peneliti untuk mendapatkan informasi yang akan menunjang dan berguna sebagai kebutuhan akan penelitian yang dilakukan. Menurut Sugiyono (2016) teknik pengumpulan data dapat dilakukan dengan observasi (pengamatan), interview (wawancara), kuesioner, dokumentasi, dan gabungan 
keempatnya. Pada penelitian kuantitatif teknik pengumpulan data yang digunakan yaitu observasi, wawancara tidak terstruktur, dan dokumentasi. Teknik pengumpulan data yang digunakan pada penelitian ini sebagai berikut.

Teknik penganalisisan data pada penelitian ini menggunakan tahapan yaitu:

1. Tabulasi data. Kegiatan pada tahap tabulasi ini berkaitan dengan memasukkan serta menyusun data ke dalam tabel-tabel yang telah disiapkan sebgai penunjang dalam pengolahan data.

2. Menentukan tingkat tingkat persentase dengan rumus:

$$
\mathrm{P}=\frac{\mathrm{F}}{\mathrm{N}} \mathrm{X} 100 \%
$$

3. Menghitung rata-rata pada setiap indikator dengan rumus

$\mathrm{X}=\frac{[\$ 4 x F+\$ 3 x f+\$ 2 x f+\$ 1 x f]}{N}$

Keterangan:

$$
\begin{array}{ll}
\text { X } & \text { : Skor rata-rata } \\
\text { S1-4 } & \text { : skor pada skala 1-4 } \\
\text { F } & \text { : frekuensi jawaban } \\
\text { N } & \text { : jumlah sampel }
\end{array}
$$

4. Langkah terakhir menafsirkan skor rata-rata ke dalam interval

Sangat positif : 3,28-4,03

Positif

Negatif $\quad: 1,76-2,51$

Sangat negatif : $1,00-1,75$

\section{HASIL DAN PEMBAHASAN}

\section{Perasaan Senang}

Pernyataan yang mewakili indikator perasaan senang dalam menghitung tingkat minat baca sebanyak empat pernyataan yang disajikan secara acak pada angket nomor 1,7,12,20 dengan sub indikator semangat dalam membaca, kesan terhadap membaca, dan bebas memilih bahan bacaan. Berikut hasil yang diberikan oleh responden dengan variasi jawaban selalu, sering, kadang-kadang, dan tidak pernah.
Tabel 1. Rekapitulasi Indikator Perasaan Senang

\begin{tabular}{clc}
\hline Tabel & Jawaban & Skor \\
\hline 4 & Positif & 2,62 \\
5 & Positif & 2,77 \\
6 & Positif & 3,0 \\
7 & Positif & 3,01 \\
\hline Total skor & & 11,4 \\
\hline $\begin{array}{c}\text { Skor rata- } \\
\text { rata }\end{array}$ & Positif & 2,85 \\
\hline
\end{tabular}

Berdasarkan rekapitulasi data pada tabel 1 skor rata-rata minat baca siswa SD Negeri 05 Kubang putiah pada indikator perasaan senang adalah 2,85. Skor ini pada interval 2,52 - 3,27, yang menunjukan bahwa minat baca siswa SD Negeri 05 Kubang Putiah berdasarkan indikator perasaan senang bernilai positif. dan mampu memberikan perasaan senang dan kesan yang baik kepada siswa yang berkaitan dengan kegiatan membaca sehingga terjadi peningkatan minat baca siswa. Perolehan nilai terendah berada pada sub indikator perasaan siswa terhadap membaca, namun nilai yang didapatkan masih menunjukan hasil yang positif. Hal ini selaras dengan pendapat Djali (2009) siswa yang memiliki minat yang tinggi akan menunjukan perasaaan senang saat melakukan kegiatan tersebut artinya sebagian besar dari siswa merasa senang untuk membaca dan hanya sebagian kecil dari siswa yang merasa bosan untuk membaca.

\section{Pemusatan Perhatian}

Pernyataan yang mewakili indikator pemusatan perhatian dalam menghitung tingkat minat baca sebanyak empat pernyataan yang disajikan secara acak pada angket nomor 2, 8, 13, 17, 22 dengan sub indikator ketertarikan untuk membaca, antusias membaca, keinginan mencari sumber bacaan, ketertarikan terhadap bahan bacaan. Berikut hasil yang diberikan oleh responden dengan variasi jawaban selalu, sering, kadang-kadang, dan tidak pernah.

Berdasarkan penilaian responden terhadap aspek-aspek pengukuran tingkat 
minat baca siswa yang diuraikan dalam pernyataan-pernyataan kuesioner pada indikator pemusatan perhatian, rekapitulasi nilainya sebagai berikut.

\section{Tabel 2.}

Rekapitulasi Indikator Pemusatan Perhatian

\begin{tabular}{cll}
\hline Tabel & \multicolumn{1}{c}{ Jawaban } & Skor \\
\hline 9 & Positif & 2,67 \\
10 & Positif & 3,04 \\
11 & Negatif & 1,98 \\
12 & Negatiff & 2,49 \\
13 & Sangat positif & 3,71 \\
\hline Total skor & & 11,4 \\
\hline $\begin{array}{c}\text { Skor rata- } \\
\text { rata }\end{array}$ & Positif & 2,78 \\
\hline
\end{tabular}

Skor rata-rata minat baca siswa SD Negeri 05 Kubang Putiah berdasarkan indikator pemusatan perhatian adalah 2,78 berada pada interval 2,52 - 3,27, yang menunjukan bahwa minat baca siswa berdasarkan indikator pemusatan perhatian adalah positif. Pada indikator pemusatan perhatian perolehan nilai terendah pada indikator keinginan mencari sumber bacaan menunjukan nilai negatif. Keinginan siswa yang rendah untuk mecari sumber bacaan dengan berkunjung ke toko buku juga disebabkan oleh lokasi sekolah yang jauh dari toko buku yang berada di pusat kota. Sedangkan keinginan siswa untuk meminjam buku di perpustakaan juga menunjukan nilai negatif karena kebanyakan dari siswa hanya sekedar membaca buku di perpustakaan sekolah atau pojok baca kelas tanpa harus meminjam untuk di bawa pulang. Hanya sebagian kecil dari siswa yang meminjam buku untuk dibawa pulang.

\section{Penggunaan Waktu}

Pernyataan yang mewakili indikator penggunaan waktu dalam menghitung tingkat minat baca sebanyak dua pernyataan yang disajikan secara acak pada angket nomor $3,18,10$ dengan sub indikator penggunaan waktu luang untuk membaca, dan frekuensi membaca. Berikut hasil yang diberikan oleh responden dengan variasi jawaban selalu, sering, kadangkadang, dan tidak pernah.

Berdasarkan penilaian responden terhadap aspek-aspek pengukuran tingkat minat baca siswa yang diuraikan dalam pernyataan-pernyataan kuesioner pada indikator penggunaan waktu, rekapitulasi nilainya sebagai berikut.

Tabel 3.

Rekapitulasi Indikator Penggunaan Waktu

\begin{tabular}{rrr}
\hline Tabel & Jawaban & \multicolumn{1}{c}{ Skor } \\
\hline 15 & Negatif & 2,09 \\
16 & Positif & 3,26 \\
17 & Positif & 2,26 \\
\hline Total skor & & 7,61 \\
\hline $\begin{array}{l}\text { Skor rata- } \\
\text { rata }\end{array}$ & Positif & 2,54 \\
\hline
\end{tabular}

Berdasarkan data pada tabel 18 terlihat skor rata-rata minat baca siswa SD Negeri 05 Kubang Putiah berdasarkan indikator penggunaan waktu adalah 2,54 berada pada interval 2,52 - 3,27, yang menunjukan bahwa minat baca siswa berdasarkan indikator penggunaan waktu adalah positif. dimana siswa sudah mampu menggunakan waktu mereka untuk membaca walaupun saat libur hanya sebagian kecil dari mereka yang mengahabiskan waktu untuk membaca.

\section{Motivasi Untuk Membaca}

Pernyataan yang mewakili indikator motivasi untuk membaca dalam menghitung tingkat minat baca sebanyak lima pernyataan yang disajikan secara acak pada angket nomor 4, 9, 19, 23, 14 dengan sub indikator ketertarikan untuk membaca, antusias membaca, keinginan mencari sumber bacaan, ketertarikan terhadap bahan bacaan. Berikut hasil yang diberikan oleh responden dengan variasi jawaban selalu, sering, kadang-kadang, dan tidak pernah.

Berdasarkan penilaian responden terhadap aspek-aspek pengukuran tingkat minat baca siswa yang diuraikan dalam pernyataan-pernyataan kuesioner pada 
indikator motivasi untuk membaca, rekapitulasi nilainya sebagai berikut.

Tabel 1.

\begin{tabular}{ccc}
\multicolumn{2}{c}{ Rekapitulasi Indikator Motivasi Untuk } \\
Membaca
\end{tabular}

Berdasarkan data pada tabel 24 terlihat skor rata-rata minat baca siswa SD Negeri 05 Kubang Putiah berdasarkan indikator motivasi untuk membaca adalah 2,79 berada pada interval $2,52-3,27$, yang menunjukan bahwa minat baca siswa berdasarkan indikator motivasi untuk membaca adalah positif. Berarti siswa telah mendapatkan motivasi untuk senantiasa membaca dari guru dan diri sendiri.

\section{Emosi dalam membaca}

Pernyataan yang mewakili indikator motivasi untuk membaca dalam menghitung tingkat minat baca sebanyak lima pernyataan yang disajikan secara acak pada angket nomor 5, 15 dengan sub indikator mampu mengambil kesimpulan dari bacaan, dan mampu memberikan pendapat dari bacaan. Berikut hasil yang diberikan oleh responden dengan variasi jawaban selalu, sering, kadang-kadang, dan tidak pernah.

Berdasarkan penilaian responden terhadap aspek-aspek pengukuran tingkat minat baca siswa yang diuraikan dalam pernyataan-pernyataan kuesioner pada indikator emosi dalam membaca, rekapitulasi nilainya sebagai berikut.

Tabel 5.

\section{Rekapitulasi Indikator Emosi Dalam} Membaca

\begin{tabular}{ccc}
\hline Tabel & Jawaban & Skor \\
\hline 25 & Positif & 2,98 \\
\hline
\end{tabular}

\begin{tabular}{ccc}
\hline 26 & Negatif & 2,18 \\
\hline Total skor & & 5,16 \\
\hline $\begin{array}{c}\text { Skor rata- } \\
\text { rata }\end{array}$ & Positif & 2,58 \\
\hline
\end{tabular}

Berdasarkan tabel 27 terlihat skor rata-rata minat baca siswa SD Negeri 05 Kubang Putiah berdasarkan indikator emosi dalam membaca adalah 2,58 berada pada interval 2,52 - 3,27, yang menunjukan bahwa minat baca siswa berdasarkan indikator emosi dalam membaca adalah positif. Berdasarkan penjelasan terkait emosi dalam membaca dapat disimpulkan bahwa siswa SD Negeri 05 Kubang Putiah telah memiliki emosi yang baik dalam membaca melalui kemampuan siswa mengambil pelajaran dari apa yang mereka baca dan mampu membacakan kembali kepada siswa lain di depan kelas. Emosi yang ditunjukan dari kemampuan mengambil pelajaran dari apa yang telah dibaca mampu meningkatkan minat baca siswa serta pengetahuan siswa dari apa yang telah mereka baca.

\section{Usaha Untu Membaca}

Pernyataan yang mewakili indikator motivasi untuk membaca dalam menghitung tingkat minat baca sebanyak lima pernyataan yang disajikan secara acak pada angket nomor 6, 11, 16, 21 dengan sub indikator mampu membaca untuk menggali informasi baru, mampu meminjam bahan bacaan . Berikut hasil yang diberikan oleh responden dengan variasi jawaban selalu, sering, kadang-kadang, dan tidak pernah.

Berdasarkan penilaian responden terhadap aspek-aspek pengukuran tingkat minat baca siswa yang diuraikan dalam pernyataan-pernyataan kuesioner pada indikator usaha untuk membaca, rekapitulasi nilainya sebagai berikut.

Tabel 6.

Rekapitulasi Indikator Usaha Untuk Membaca

\begin{tabular}{ccc}
\hline Tabel & Jawaban & Skor \\
\hline 28 & Negatif & 2,5 \\
29 & Negatif & 1,92 \\
30 & Positif & 2,87 \\
\hline
\end{tabular}




\begin{tabular}{ccc}
\hline 31 & Sangat positif & 3,67 \\
\hline Total skor & & 10,96 \\
\hline $\begin{array}{c}\text { Skor rata- } \\
\text { rata }\end{array}$ & Positif & 2,74 \\
\hline
\end{tabular}

Berdasarkan data pada tabel 32 terlihat skor rata-rata minat baca siswa SD Negeri 05 Kubang Putiah berdasarkan indikator usaha untuk membaca adalah 2,74 berada pada interval $2,52-3,27$, yang menunjukan bahwa minat baca siswa berdasarkan indikator emosi dalam membaca adalah positif yang berarti bahwa siswa dan pihak sekolah memiliki keinginan berusaha agar tujuan untuk meningkatkan minat baca tercapai. Usaha tersebut dibuktikan dengan adanya bahan bacaan yang tersedia di pojok baca kelas dan dapat diguanakan oleh siswa kapan saja mereka ingin membaca.

Berdasarkan penilaian responden terhadap aspek-aspek pengukuran tingkat minat baca siswa yang diuraikan dalam pernyataan-pernyataan kuesioner pada seluruh indikator minat baca, rekapitulasi nilainya sebagai berikut.

\section{Tabel 7.}

Rekapitulasi Indikator Minat Baca Siswa

\begin{tabular}{ccc}
\hline Tabel & Jawaban & Skor \\
\hline Perasaan senang & Positif & 2,85 \\
Pemusatan perhatia: & Positif & 2,78 \\
Penggunaan waktu & Positif & 2,54 \\
Motivasi untuk & Positif & 2,79 \\
membaca & & \\
Emosi dalam & Positif & 2,58 \\
membaca & & \\
Usaha untuk & Positif & 2,74 \\
membaca & & \\
\hline Total skor & & 16,28 \\
\hline Skor rata-rata & Positif & 2,71 \\
\hline
\end{tabular}

Berdasarkan data pada tabel 33 terlihat skor rata-rata minat baca siswa SD Negeri 05 Kubang putiah berdasarkan indikator minat baca adalah 2,71 berada pada interval $2,52-3,27$, yang menunjukan bahwa tingkat minat baca siswa SD Negeri 05 Kubang Putiah adalah positif.

\section{SIMPULAN}

Berdasarkan hasil hitung dan pembahasan yang telah diuraikan maka hasil penelitian ini sebagai berikut: (1) perasaan senang bernilai positif dengan skor 2,85 yang menunjukan siswa merasa senang membaca buku; (2) indikator pemusatan perhatian bernilai positif dengan skor 2,78 yang menunjukan perhatian siswa untuk kegiatan membaca baik; (3) indikator penggunaan waktu bernilai positif dengan skor 2,54 yang menunjukan siswa sudah mempu menggunakan waktu secara efesien untuk membaca; (4) indikator motivasi untuk membaca bernilai positif dengan skor 2,79 yang menunjukan siswa memiliki motivasi yang baik untuk membaca; (5) indikator emosi dalam membaca bernilai positif dengan skor 2,58 yang menunjukan siswa mampu menunjukan emosi yang baik saat membaca; (6) indikator usaha untuk membaca bernilai positif dengan skor 2,74 yang menunjukan siswa telah melakukan usaha untuk bisa membaca. Secara keseluruhan tingkat minat baca Siswa SD Negeri 05 Kubang Putiah melalui penerapan Drop Everything And Read (DEAR) bernilai positif dengan skor 2,71 yang menunjukan tingkat minat baca siswa SD Negeri 05 Kubang Putiah dinilai baik. Skor tertinggi pada indikator perasaan senang dan skor terendah pada indikator penggunaan waktu.

\section{SARAN}

Bagi penulis, setelah diketahui tingkat minat baca siswa dari sampel penelitian diharapkan dapat dikembangkan dengan penelitian-penelitian terkait dimasa datang. Bagi pembaca, tingkat minat baca siswa dapat dijadikan acuan untuk menambah wawasan guna dijadikan acuan untuk penelitian selanjutnya. Bagi SD Negeri 05 Kubang Putiah dapat mengetahui tingkat minat baca siswa guna menjadikan bahan evaluasi terkait minat baca siswa melalui penerapan Drop Everything And Read (DEAR) dan dapat memaksimalkan penerapan Drop Everything And Read (DEAR) agar minat baca siswa selalu bertambah dimasa akan datang. 


\section{DAFTAR PUSTAKA}

Djali. (2009) psikologi Pendidikan. Jakarta: Bumi Aksara.

Kominfo. (2017). Teknologi Masyarakat Indonesia: Malas Baca Tapi Cerewet di Medsos. Jakarta: Kementerian Komunikasi dan Informatika. http://kominfo.go.id/content (diakses 23 Maret 2021)

Shaleh, A. R., dkk. (2004). Psikologi Suatu pengantar dalam Perspektif Islam. Jakarta: Kencana
Sugiyono. (2017). Metode Penelitian Kombinasi. Bandung: Alfabeta.

Usaid Prioritas. (2015). Buku Sumber Untuk Pembelajaran Literasi di Sekolah Dasar/Madrasah Ibtidaiyah. Jakarta.

Usaid Prioritas. (2015). Pembelajaran Literasi di Sekolah Dasar/MI. Jakarta. 